\title{
TANGGUNG GUGAT PENGEMBANG KEPADA PEMBELI AKIBAT WANPRESTASI TERHADAP PRASARANA, SARANA DAN UTILITAS UMUM DALAM PELAKSANAAN PERJANJIAN PENGIKATAN JUAL BELI SATUAN RUMAH SUSUN
}

\author{
Gavin Samir \\ Magister Kenotariatan, Fakultas Hukum, Universitas Airlangga Surabaya \\ e-mail: gavin.samir@yahoo.com
}

\begin{abstract}
ABSTRAK
Dewasa ini untuk memenuhi kebutuhan masyarakat akan tempat tinggal yang layak di tengah pesatnya pertumbuhan ekonomi dan semakin berkurangnya ketersediaan tanah, maka dibangun tempat tinggal dalam bentuk rumah susun. Rumah susun merupakan bangunan gedung bertingkat yang digunakan untuk tempat hunian yang diatur dalam Undang-Undang Nomor 20 Tahun 2011 tentang Rumah Susun. Pada artikel ini penyusun memfokuskan pada bentuk tanggung gugat pengembang kepada pembeli akibat wanprestasi pada prasarana, sarana, dan utilitas umum dalam pelaksanaan perjanjian pengikatan jual beli satuan rumah susun, dan upaya hukum pembeli yang dapat dilakukan dengan cara menggugat pengembang yang wanprestasi secara perdata melalui pengadilan atau di luar pengadilan.
\end{abstract}

Kata Kunci: tanggung gugat; pengembang; wanprestasi; rumah susun

\section{ABSTRACT}

Nowadays to fulfill people's need for decent housing in the midst of rapid economic growth and decreasing of soil availability, then, it's built in the form of flats. Flats are high rise buildings used for shelter as regulated in Act Number 20/2011 About Flats. In this article, the authors focus on developer liability to buyers as a result of in default on public utilities, facilities and utilities in the implementation of sale and purchase agreements and the buyer's legal efforts that can be done by suing a developer who in default with civil rights through the court or outside court.

Keywords: liability; developer; in default; flats

\section{PENDAHULUAN}

Perkembangan pembangunan di kota-kota besar setiap tahunnya mengalami peningkatan dengan cepat. Proses perkembangan yang cepat di kotakota besar ini disebabkan oleh adanya aktivitas di perkotaan yang menimbulkan daya tarik tersendiri serta fungsi kota sebagai pusat pemerintahan, pusat perdagangan, pusat industri dan lain-lain. Meningkatnya pembangunan tersebut berbanding lurus dengan meningkatnya kepadatan wilayah di kota-kota besar. Perlu diketahui bahwa pada dasarnya setiap manusia memiliki kebutuhan pokok (primer) yaitu sandang, pangan, dan papan. Akibat dari meningkatnya kepadatan wilayah di kota-kota besar ini, menyebabkan masyarakat di perkotaan semakin kesulitan dalam memenuhi salah satu kebutuhan pokoknya, yaitu kebutuhan akan papan yang dalam hal ini untuk memiliki rumah tinggal.

Sejalan dengan Undang-Undang Dasar Negara Republik Indonesia Tahun 1945 (selanjutnya disebut UUD 1945) dalam Pasal $28 \mathrm{H}$ ayat (1) yang menegaskan bahwa setiap orang berhak untuk hidup sejahtera lahir dan batin, mempunyai 
tempat tinggal, dan mendapatkan lingkungan hidup yang baik serta sehat. Oleh karena itu, tidak jarang masyarakat Indonesia berkeinginan mendapatkan sebuah tempat tinggal yang baik untuk dirinya. Tempat tinggal mempunyai peran yang penting dan strategis dalam pembentukan watak dan kepribadian bangsa, serta sebagai salah satu upaya membangun manusia Indonesia seutuhnya, berjati diri, mandiri dan produktif. ${ }^{1}$

Pada dasarnya pemenuhan kebutuhan akan rumah sebagai tempat tinggal atau hunian merupakan tanggung jawab masyarakat itu sendiri. Namun demikian, pemerintah, pemerintah daerah dan perusahaan swasta yang bergerak dalam bidang pembangunan perumahan didorong untuk dapat membantu masyarakat dalam pemenuhan kebutuhan akan rumah sebagai tempat tinggal atau hunian. ${ }^{2}$

Banyaknya permintaan rumah tinggal dengan tanah yang semakin terbatas terutama di daerah perkotaan memberikan peluang bisnis bagi pelaku usaha di bidang perumahan, atau bisa disebut dengan pengembang (developer). Namun dengan banyaknya permintaan rumah tinggal tersebut menyebabkan sektor usaha ini menghadapi tantangan yang semakin berat untuk mendapatkan tempat-tempat yang strategis. Dengan keterbatasan yang seperti ini untuk membangun rumah tinggal sebagai tempat hunian yang layak membuat para pengembang menciptakan berbagai solusi untuk menyiasatinya. Salah satunya yaitu dengan cara melakukan pembangunan rumah susun.

Lahirnya Undang-Undang Republik Indonesia Nomor 20 Tahun 2011 tentang Rumah Susun (selanjutnya disebut UURS), undang-undang ini menciptakan dasar hukum yang tegas berkaitan dengan penyelenggaraan rumah susun dengan berdasarkan asas kesejahteraan, keadilan dan pemerataan, kenasionalan, keterjangkauan dan kemudahan, keefisienan dan kemanfaatan, kemandirian dan kebersamaan, kemitraan, keserasian dan keseimbangan, keterpaduan, kesehatan, kelestarian dan berkelanjutan, keselamatan, kenyamanan, dan kemudahan, serta keamanan, ketertiban, dan keteraturan seperti yang tercantum di Pasal 2 UURS. Dalam Undang-Undang ini

\footnotetext{
1 Urip Santoso. (2014). Hukum Perumahan. Jakarta: Kencana Prenada Media Group, h. 2.

2 ibid.
}

penyelenggaraan rumah susun bertujuan untuk menjamin terwujudnya rumah susun yang layak huni dan terjangkau, meningkatkan efisiensi dan efektivitas pemanfaatan ruang, mengurangi luasan dan mencegah timbulnya perumahan dan permukiman kumuh, mengarahkan pengembangan kawasan perkotaan, memenuhi kebutuhan sosial dan ekonomi, memberdayakan para pemangku kepentingan, serta memberikan kepastian hukum dalam penyediaan, kepenghunian, pengelolaan, dan kepemilikan rumah susun.

Dalam Undang-Undang Nomor 1 Tahun 2011 tentang Perumahan dan Kawasan Permukiman (selanjutnya disebut UU Perumahan), ditetapkan bahwa rumah dapat berfungsi sebagai: a. Pemenuhan kebutuhan dasar; b. Tempat tinggal atau hunian; c. Asset (kekayaan) bagi pemiliknya; d. Status sosial dan ekonomi bagi pemiliknya; e. Tempat untuk mendapatkan penghasilan atau keuntungan; f. Sarana pembinaan keluarga, cerminan harkat dan martabat bagi pemiliknya; g. Penunjang pelaksanaan tugas pejabat dan/atau pegawai negeri. ${ }^{3}$

Pemenuhan kebutuhan tempat tinggal salah satunya dapat dilakukan melalui pembangunan rumah susun sebagai bagian dari pembangunan perumahan, mengingat semakin banyaknya jumlah penduduk baik yang berasal dari pertumbuhan penduduk yang bersifat alamiah melalui kelahiran maupun urbanisasi, serta keterbatasan tanah yang ada di perkotaan untuk pembangunan perumahan. Pembangunan rumah susun disamping merupakan salah satu alternatif pemenuhan kebutuhan akan rumah sebagai tempat tinggal atau hunian bagi warga kota yang padat penduduknya, juga merupakan pengembangan wilayah kota secara vertikal. ${ }^{4}$

Siswono Judohusodo menyatakan "bahwa membangun rumah susun di kota besar adalah kecenderungan masa depan yang tidak dapat dihindari, yang memang perlu dimasyarakatkan, dan perlu ada penyesuaian pada budaya yang ada pada masyarakat Indonesia." Pembangunan rumah susun dengan sistem vertikal rupanya sangat membantu masyarakat yang tinggal di kota padat penduduk, karena meskipun persediaan tanah terbatas (relatif tetap) khususnya di kota-kota besar, masyarakat tetap dapat memiliki tempat tinggal dan rumah susun dapat

\footnotetext{
3 ibid.

4 ibid., h. 402.
} 
diperuntukkan bagi masyarakat berpenghasilan atas, menengah dan rendah. ${ }^{5}$

Pada dasarnya pembangunan rumah susun di Indonesia juga merupakan salah satu dari tujuan Pembangunan Nasional yaitu untuk mewujudkan suatu masyarakat adil dan makmur yang merata materiil dan spiritual berdasarkan Pancasila dan UUD 1945, Pembangunan rumah susun khususnya di kawasan perkotaan di dasarkan pada konsep pembangunan berkelanjutan, yang menempatkan manusia sebagai pusat pembangunan. ${ }^{6}$

Berbagai motivasi masyarakat ingin memiliki rumah susun sebagai tempat tinggal, gaya hidup (life style), sebagai sarana investasi, atau keperluan usaha, membuat permintaan akan rumah susun semakin meningkat, dan para pengembang pelaku pembangunan rumah susun berlomba-lomba untuk dapat memenuhi kebutuhan masyarakat akan rumah susun, sehingga membuat perkembangan ekonomi nasional mengalami peningkatan yang searah.

Demi mewujudkan perkembangan ekonomi tersebut pemerintah juga memberikan dukungan kepada para pengusaha properti melalui kemudahan regulasi dalam hal perijinan dan dalam hal pemasaran di bidang Rumah Susun/Apatemen meskipun pembangunan rumah susun tersebut belum selesai seperti yang tertuang di dalam Pasal 43 ayat (1) dan (2) UURS, yang menyebutkan bahwa: 1) Proses jual beli satuan rumah susun sebelum pembangunan rumah susun selesai dapat dilakukan melalui PPJB yang dibuat dihadapan notaris; 2) PPJB sebagaimana dimaksud pada ayat (1) dilakukan setelah memenuhi persyaratan kepastian atas: a. Status kepemilikan tanah; b. Kepemilikan IMB; c. Ketersediaan prasarana, sarana, dan utilitas umum; d. Keterbangunan paling sedikit 20\% (dua puluh persen); dan e. Hal yang diperjanjikan.

Semakin meningkatnya kebutuhan akan rumah susun pengembang rumah susun dan dengan diberinya kemudahan regulasi dalam hal pemasaran sesuai dengan Pasal 43 UURS tersebut dapat disimpulkan pihak pengembang dapat memperoleh dana penjualan satuan unit rumah susun meskipun pembangunan belum melalui Perjanjian Pengikatan

${ }^{5}$ Siswono Judohusodo. (1991). Rumah untuk Seluruh Rakyat. Jakarta: INKOPPOL, Unit Percetakan Bharakerta, h, 27.

${ }^{6}$ Adrian Sutedi. (2010). Hukum Rumah Susun dan Apartemen. Jakarta: Sinar Grafika, h. 180.
Jual Beli (selanjutnya disebut PPJB) dengan adanya syarat tersebut, sehingga pada akhirnya pengembang berlomba-lomba dalam menawarkan rumah susun yang dibangunnya dengan menawarkan berbagai prasarana, sarana dan utilitas umum yang memadai agar rumah susun yang dibangunnya dapat menarik minat pembeli. Penyediaan Prasarana, sarana dan utilitas umum oleh pengembang merupakan amanat dari Pasal 40 ayat (1) UURS di mana pengembang wajib melengkapi lingkungan rumah susun dengan prasarana, sarana dan utilitas umum.

Meskipun telah diamanatkan oleh Pasal 40 ayat (1) UURS nyatanya masih banyak pengembang yang nakal dan tidak memenuhi prasarana, sarana dan utilitas umum seperti yang dijanjikan oleh pengembang kepada pembeli, seperti yang terjadi di Jakarta yang dilakukan oleh Pengembang dari Apartemen Green Pramuka City yakni PT. Duta Paramindo Sejahtera, dimana salah satu pembelinya yakni Muhadkly MT alias Acho yang menagih janji fasilitas yang tertera dalam brosur apartemen yang berkonsep green living, di mana $80 \%$ area apartemennya adalah ruang terbuka hijau, namun kenyataannya saat ini Apartemen Green Pramuka City sedang membangun 17 tower di atas tanah tersebut, sehingga janji $80 \%$ area terbuka hijau atau green living seluas 10,3 Hektar tidak terealisasi, selain itu kerugian lain yang diterima oleh Acho adalah lahan parkir yang disediakan awalnya untuk penghuni dengan keputusan sepihak dari pengembang Apartemen Green Pramuka para penghuni hanya boleh memarkir kendaraannya di area basement dengan membayar tarif tambahan per jamnya yang dirasa sangat merugikan penghuni karena telah dibebani tarif parkir per-bulannya, selain itu tidak adanya fasilitas lift pada area parkir basement menuju ke lobby apartemen membuat para penghuni tersebut harus menggunakan tangga untuk menuju ke lobby yang dirasa cukup melelahkan untuk penghuni khususnya kepada penghuni lansia ataupun penghuni yang memiliki keterbatasan fisik, selain itu sarana olahraga yang dijanjikan oleh pihak pengembang apartemen seperti tempat gym, lapangan tennis, basket, dan golf juga belum terealisasi padahal penghuni juga telah membayar Iuran Pengelolaan Lingkungan setiap bulannya dan Biaya Peningkatan Mutu yang jumlahnya sangat besar saat membeli unit tersebut. 


\section{PERUMUSAN MASALAH}

Berdasarkan hal tersebut, dapat diketahui posisi pembeli yang sangat dirugikan dan tidak berdaya menghadapi pengembang Apartemen Green Pramuka City yang tidak memenuhi fasilitas yang diperjanjikan sebelumnya dengan pembeli, sehingga beranjak dari kasus di atas penulis ingin menulis artikel ini mengenai bagaimana tanggung gugat yang harus dilakukan oleh pihak pengembang apabila wanprestasi dengan pembeli dan bagaimana upaya hukum pembeli dalam mengatasi wanprestasi yang dilakukan oleh pihak pengembang.

\section{PEMBAHASAN}

\section{Perjanjian Pengikatan Jual Beli Sebagai Perjanjian Pendahuluan Dalam Jual Beli Satuan Rumah Susun}

Perjanjian pengikatan jual beli (selanjutnya disebut PPJB) pada dasarnya merupakan perjanjian pada umumnya. Hanya saja PPJB merupakan perjanjian yang lahir dari kebutuhan praktik dan diakomodasi berdasarkan asas kebebasan berkontrak. Hal ini merupakan konsekuensi dari adanya sifat terbuka dari Buku III BW, yang memberikan kebebasan seluas-luasnya kepada setiap subyek hukum untuk membuat perjanjian dengan isi maupun bentuknya, asalkan tidak bertentangan dengan peraturan perundang-undangan, ketertiban umum dan kesusilaan.

Pengikatan jual beli menurut Subekti adalah perjanjian antara pihak Penjual dan pihak pembeli sebelum dilaksanakannya jual beli dikarenakan adanya unsur-unsur yang harus dipenuhi untuk jual beli tersebut antara lain adalah sertipikat hak atas tanah belum ada karena masih dalam proses atau belum terjadinya pelunasan harga atau pajak-pajak yang dikenakan terhadap jual beli hak atas tanah belum dapat dibayar baik oleh penjual atau pembeli. ${ }^{7}$

Menurut Herlien Budiono, perjanjian ikatan jual beli adalah perjanjian obligatoir. Perjanjian obligatoir adalah perjanjian yang timbul karena kesepakatan dari dua pihak atau lebih dengan tujuan untuk timbulnya suatu perikatan. Selain itu, perjanjian ikatan jual beli merupakan perjanjian bantuan yang berfungsi sebagai perjanjian pendahuluan dan bentuknya bebas. Maksudnya adalah dalam perjanjian ikatan jual beli

\footnotetext{
${ }^{7}$ Subekti. (1995). Aneka Perjanjian. Bandung: Citra Aditya Bakti, h. 75.
}

para pihak saling mengikatkan diri untuk terjadinya suatu perjanjian pokok yang merupakan tujuan dari para pihak, yaitu jual beli dihadapan PPAT. ${ }^{8}$

PPJB termasuk ruang lingkup hukum perjanjian sebagimana diatur dalam Bagian Kelima tentang perikatan-perikatan bersyarat yaitu dalam Pasal 1253 sampai dengan Pasal 1267 BW, sedangkan jual beli satuan rumah susun termasuk ruang lingkup hukum tanah yang tetuang dalam UUPA. Dalam hukum perjanjian dikenal adanya asas daya mengikat perjanjian bagi para pihak yang memperjanjikannya (pacta sunt servanda) dan bagi para pihak bebas menentukan bentuk dan isi perjanjiannya berdasarkan asas kebebasan berkontrak sebagaimana diatur dalam Pasal 1338 BW. Semua perjanjian yang dibuat harus memenuhi unsur Pasal 1320 BW, sehingga PPJB juga harus memenuhi syarat sah suatu perjanjian.

Sebagai perjanjian yang lahir karena adanya kebutuhan praktik dan tidak diatur secara tegas dalam peraturan perundang-undangan, maka PPJB tidak mempunyai bentuk tertentu. Namun demikian tentunya perjanjian tersebut harus melindungi proses bisnis para pihak dan memenuhi syarat sahnya perjanjian.

Pasal 1320 BW memberikan rumusan 4 (empat) syarat sahnya kontrak tersebut yang dikaitkan pada Pasal-pasal yang berhubungan dengan masingmasing syarat, meliputi: a. sepakat mereka yang mengikatkan diri (vide Pasal 1321-1328 BW); b. Kecakapan untuk membuat suatu perikatan (vide Pasal $13291331 \mathrm{BW}$ ); c. Suatu hal tertentu (vide Pasal 1332 -1334 BW); d. Suatu sebab yang halal atau diperbolehkan (vide Pasal 1335 -1337 BW).

Sehubungan dengan keempat syarat dalam Pasal 1320 BW tersebut di atas terdapat penjelasan lebih lanjut terkait dengan konsekuensi tidak dipenuhinya masing-masing syarat dimaksud. Pertama, syarat kesepakatan dan kecakapan, merupakan unsur subyektif karena berkenaan dengan diri orang atau subyek yang membuat kontrak. Kedua, syarat obyek tertentu dan causa yang diperbolehkan merupakan unsur obyektif.

Suatu kontrak yang tidak memenuhi syarat sah sebagaimana yang diatur dalam Pasal 1320 BW, baik syarat subyektif maupun syarat obyektif

${ }^{8}$ Herlien Budiono. (2008). Kumpulan Tulisan Hukum Perdata di Bidang Kenotariatan. Bandung: Citra Aditya Bakti, h. 268-270. 
akan mempunyai akibat-akibat, sebagai berikut: a. "noneksistensi" apabila tidak ada kesepakatan maka tidak timbul kontrak; b. vermetigbaar atau dapat dibatalkan, apabila kontrak tersebut lahir karena adanya cacat kehendak atau karena ketidakcakapan (Pasal 1320 BW syarat 1 dan 2), berarti hal ini terkait dengan unsur subyektif; sehingga berakibat kontrak tersebut dapat dibatalkan dan; c. nietig atau batal demi hukum, apabila terdapat kontrak yang tidak memenuhi syarat obyek tertentu atau tidak mempunyai causa atau causanya tidak diperbolehkan (Pasal 1320 BW syarat 3 dan 4), berarti hal ini terkait dengan unsur subyektif, sehingga berakibat kontrak tersebut batal demi hukum. ${ }^{9}$

Dari aspek hukum pertanahan sering diperdebatkan apakah pelaksanaan pengikatan jual beli tersebut di atas dapat dibenarkan. Sebagaimana diketahui jual beli dalam hukum tanah bersifat tunai, riil dan terang. Tunai dalam hukum adat tidaklah harus dibayar kontan, walaupun hanya dibayar sebagian saja maka sudah termasuk tunai, dan selanjunya sisa uang yang belum dibayar tunduk pada utang piutang. Senada dengan hal tersebut Maria SW Sumardjono mengemukakan bahwa yang dimaksud tunai adalah bahwa penyerahan hak oleh penjual dilakukan bersamaan dengan pembayaran oleh pembeli dan seketika itu juga hak sudah beralih. Harga yang dibayar itu tidak harus lunas, selisih harga dianggap sebagai utang pembeli kepada penjual yang termasuk dalam lingkup hukum utang piutang. Sedangkan riil adalah kehendak yang diucapkan harus diikuti dengan perbuatan nyata, sedangkan terang perbuatan tersebut dilakukan dihadapan kepala adat atau kepala desa untuk memastikan kalau perbuatan tersebut tidak melanggar ketentuan hukum yang berlaku. ${ }^{10}$

Pengikatan jual beli termasuk perjanjian akan melakukan jual beli tanah secara riil dihadapan PPAT. Jadi ketika seseorang melakukan perjanjian pengikatan jual beli maka hal tersebut belum dapat dikatakan teijadi jual beli dalam arti perbuatan jual beli yang tunai, riil dan terang. Pengikatan jual beli hanyalah kesepakatan para pihak bahwa suatu saat nanti para pihak akan melakukan jual beli riil.

${ }^{9}$ Agus Yudha Hernoko. (2009). Hukum Perjanjian Asas Proporsionalitas dalam Kontrak Komersial. Surabaya: Prenada Media Group, h. 160-161.

${ }^{10}$ Maria S.W. Sumardjono. (2001). Kebijakan Pertanahan Antara Regulasi \& Implementasi. Jakarta: Kompas, h. 119.
Jadi pengikatan jual beli masih termasuk hukum peijanjian yang memberikan kewajiban kepada para pihak bahwa pada suatu saat nanti akan dilakukan jual beli riil dihadapan PPAT. Dalam hal jual beli hak milik atas satuan rumah susun maka pelaksanaan jual beli riil dihadapan PPAT akan dilaksanakan jika bangunan telah selesai dibangun, bersertipikat dan telah memiliki izin layak huni. ${ }^{11}$

Ditinjau dari akibat hukumnya, dalam PPJB menimbulkan kewajiban para pihak untuk melakukan prestasi masing masing di kemudian hari, sedangkan jual beli sebagai perbuatan hukum yang bersifat tunai, riil dan terang akibat hukumnya timbul serentak atau bersamaan dengan pelaksanaan prestasi atau kewajiban kedua pihak saat itu juga. ${ }^{12}$

Dengan demikian konstruksi jual beli satuan rumah susun yang didahului pengikatan jual beli dan kemudian dilanjutkan dengan jual beli riil dengan akta PPAT dapat dibenarkan karena keduanya merupakan hal yang berbeda serta akibat hukumnya juga berbeda. Artinya dalam perjanjian pengikatan jual beli akta yang sudah dibuat tersebut dapat dilakukan pembatalan apabila para pihak menghendaki. Sedangkan dalam akta jual beli tidak dapat dilakukan pembatalan karena dalam proses penandatanganan akta jual beli hak kepemilikan sudah langsung beralih dan bukti kepemilikan sudah dapat langsung dibalik nama ke atas nama pembeli dengan melakukan pendaftaran peralihan hak melalui Kantor Pertanahan setempat.

\section{Wanprestasi dan Bentuk Tanggung Gugat Pengembang Kepada Pembeli Satuan Rumah Susun terhadap Sarana, Prasana, dan Fasilitas Umum}

Prestasi dalam hukum kontrak dimaksudkan sebagai suatu pelaksanaan hal-hal tertulis dalam suatu kontrak oleh pihak yang telah mengikatkan diri untuk itu, pelaksanaan mana sesuai dengan "term" dan "condition" sebagaimana disebutkan dalam kontrak yang bersangkutan. Sedang dalam hubungan dengan hubungan para pihak dalam perjanjian, prestasi dikaitkan dengan sifat dan luasnya kewajiban para pihak. ${ }^{13}$

\footnotetext{
${ }^{11}$ ibid., h. 116.

12 ibid.

${ }^{13}$ Munir Fuadi. (1999). Hukum Kontrak (Dari Sudut Pandang Hukum Bisnis). Bandung: Citra Aditya, h. 87.
} 
Tanggung gugat mengandung esensi untuk membayar sejumlah ganti rugi karena kesalahan yang dilakukan. Apa yang mengikat para pihak adalah apa yang telah disepakati. Kewajiban yang dipertukarkan dalam perjanjian itulah yang mengikat. Yang mengikat dari suatu perjanjian adalah isi dari perjanjian tersebut.

Perikatan yang bersifat timbal balik yang menimbulkan hak bagi kreditor untuk menuntut pemenuhan prestasi yang sebaliknya juga menimbulkan beban kewajiban bagi debitor untuk melaksanakan prestasinya. Pada situasi normal antara prestasi dan kontra prestasi akan saling bertukar, namun pada kondisi tertentu pertukaran prestasi tidak berjalan sebagaimana mestinya sehingga muncul peristiwa yang disebut wanprestasi.

Sementara itu wanprestasi memiliki pengertian yaitu tidak dilaksanakan prestasi atau kewajiban sebagaimana mestinya yang disebabkan oleh kontrak terhadap pihak-pihak tertentu seperti yang disebutkan dalam kontrak yang bersangkutan. Pelanggaran hakhak kontraktual tersebut menimbulkan kewajiban ganti rugi berdasarkan wanprestasi, sebagimana diatur dalam Pasal 1236 jo. 1239 BW.

Pasal 1236 BW terkait prestasi untuk memberikan sesuatu menyatakan: "Debitur wajib memberi ganti biaya, kerugian dan bunga kepada kreditur bila ia menjadikan dirinya tidak mampu untuk menyerahkan barang itu atau tidak merawatnya dengan sebaikbaiknya untuk menyelamatkannya." Sedang Pasal 1239 BW terkait prestasi untuk berbuat atau tidak berbuat sesuatu menyatakan: "Tiap perikatan untuk berbuat sesuatu, atau untuk tidak berbuat sesuatu, wajib diselesaikan dengan memberikan penggantian biaya, kerugian dan bunga, bila debitur tidak memenuhi kewajibannya."

Pada umumnya wanprestasi terjadi ketika debitur dinyatakan lalai dalam melaksanakan kewajibannya. Hal ini sejalan dengan ketentuan Pasal 1243 BW yang menyebut bahwa: "Penggantian biaya, rugi dan bunga karena tak dipenuhinya suatu perikatan, barulah mulai diwajibkan, apabila si berutang, setelah dinyatakan lalai memenuhi perikatannya, tetap melalaikannya, atau jika sesuatu yang harus diberikan atau dibuat dalam tenggang waktu yang telah dilampaukannya."

Tindakan wanprestasi membawa konsekuensi bagi pihak yang merasa dirugikan untuk menuntut pihak yang membawa kerugian tersebut dengan meminta ganti rugi atas tindakannya tersebut. Kesalahan dalam kualifikasi culpa in contrahendo menimbulkan tanggung gugat pada pelaku atau dengan kata lain melahirkan hak pada pihak yang dirugikan untuk menuntut kerugian atas biaya dan hilangnya waktu karena gagalnya suatu negosiasi dari para pihak.

Pada para pihak dalam suatu perjanjian terletak kewajiban untuk saling memenuhi prestasi, dan jika para pihak tidak melaksanakan kewajibannya tersebut bukan oleh karena keadaan memaksa, maka para pihak yang tidak melaksanakan kewajibannya dianggap melakukan wanprestasi.

Keadaan memaksa (overmacht) adalah suatu keadaan yang terjadi setelah dibuatnya perjanjian, yang mengahalangi debitur untuk memenuhi prestasinya, dimana debitur tidak dapat dipersalahkan dan tidak harus menanggung risiko, serta tidak dapat menduga pada waktu perjanjian dibuat. Kesemuanya itu terjadi sebelum terdapat debitur lalai untuk memenuhi prestasinya pada saat timbulnya keadaan tersebut.

Terdapat beberapa bentuk wanprestasi yaitu berupa: a. Para pihak sama sekali tidak berprestasi. Dalam hal ini, para pihak baik pengembang sebagai penjual dan pembeli sama sekali tidak memberikan prestasi. Hal tersebut dapat disebabkan oleh karena memang para pihak tidak mau berprestasi lagi; $b$. Para pihak keliru berprestasi. Para pihak dalam hal ini dalam pemikirannya telah memberikan prestasinya, namun dalam kenyataannya yang diterima oleh para pihak yang menerima prestasi tersebut tidak seperti yang telah diperjanjikan. Pihak pembeli telah menyerahkan uang tanda jadi dan angsuran pembelian kepada penjual, tetapi penjual menyerahkan barang tidak seperti yang telah diperjanjikan dalam perjanjian; c. Para pihak terlambat berprestasi. Pada peristiwa ini para pihak telah saling melakukan keterlambatan dalam melakukan prestasi. Baik pihak penjual yang terlambat menyerahkan barang, ataupun juga pihak pembeli terlambat untuk melakukan kewajiban dalam pembayaran barang yang diperjualbelikan.

Dalam tindakan wanprestasi apabila para pihak baik penjual maupun pembeli yang melakukan wanprestasi, maka para pihak yang merasa dirugikan harus membuktikan kerugian yang 
dialami tersebut. Terjadinya wanprestasi dalam suatu perjanjian membawa konsekuensi bagi pihak yang melakukannya. Apabila yang melakukan wanprestasi debitur, maka akibatnya debitur harus mengganti kerugian, benda yang menjadi objek perikatan, sejak terjadinya wanprestasi menjadi tanggung gugat bagi debitur, jika perikatan itu timbul dari perikatan timbal balik maka kreditur dapat meminta pembatalan (pemutusan) perjanjian. Tuntutan wanprestasi dapat berupa pembatalan perjanjian, pemenuhan perjanjian, pembayaran ganti rugi, pembatalan perjanjian dengan ganti rugi, pemenuhan perjanjian dengan ganti rugi.

Pengingkaran terhadap perjanjian melahirkan hak bagi pihak lain untuk mengajukan gugatan atas dasar wanprestasi. Pihak yang dirugikan mempunyai hak mengajukan gugatan, sebagaimana Pasal 1267 BW, menyebutkan tuntutan tersebut dapat berupa pemenuhan, ganti rugi dan pembubaran/pemutusan. Khusus untuk ganti rugi tidak tertutup kemungkinan gugatan atas kerugian dapat berupa keuntungan yang diharapkan. Dengan demikian beranjak dari rumusan ketentuan Pasal 1267 BW, dalam hal terjadi wanprestasi maka pihak yang dirugikan dapat mengajukan tuntutuan: a. Pemenuhan (nakoming); atau b. Ganti Rugi (vervangende vergoeding; schadeloosstelling); atau c. Pembubaran, pemutusan atau pembatalan (ontbinding), atau d. Pemenuhan ditambah ganti rugi pelengkap (nakoming en anvullend vergoeding); atau e. Pembubaran ditambah ganti rugi pelengkap (ombinding en anvullend vergoeding).

Ganti rugi merupakan upaya untuk memulihkan kerugian yang prestasinya tidak lagi dimungkinkan atau sudah tidak diharapkan lagi, maka ganti rugi merupakan alternatif yang dapat dipilih oleh pihak yang dirugikan sesuai dengan ketentuan Pasal 1243 BW. Menurut Niewenhuis kerugian diartikan berkurangnya harta kekayaan pihak satu (pihak yang dirugikan) yang disebabkan oleh perbuatan (baik melakukan atau membiarkan yang melanggar norma (wanprestasi oleh pihak lain). Kerugian dibentuk oleh perbandingan antara situasi sesungguhnya (kenyataan) dengan situasi hipotesis (bagaimana seandainya tidak terjadi pelanggaran norma wanprestasi). Kerugian disini terdiri dari dua unsur yaitu kerugian yang nyata diderita meliputi biaya, rugi. Unsur yang kedua keuntungan yang tidak diperoleh, yaitu berupa bunga. Ganti rugi pada dasarnya merupakan upaya untuk memulihkan kerugian yang prestasinya bersifat subsidair. Artinya, apabila pemenuhan prestasi tidak lagi dimungkinkan atau sudah tidak diharapkan lagi maka ganti rugi merupakan alternatif yang dapat dipilih oleh kreditor. Sesuai dengan ketentuan Pasal 1243 BW, ganti rugi meliputi: biaya (kosten), rugi (schaden) dan bunga (interessen). Menurut Purwahid Patrik kerugian disini terdiri dari dua unsur, yaitu pertama, kerugian yang nyata diderita (damnum emergens), meliputi: biaya dan rugi, dan kedua keuntungan yang tidak diperoleh (lucrum cessans), berupa bunga. ${ }^{14}$

Dalam hal ini ganti rugi meliputi ganti rugi pengganti (vervangende vergoeding) dan ganti rugi pelengkap (aanvullend vergoeding). Ganti rugi pengganti (vervangende vergoeding), merupakan ganti rugi yang diakibatkan oleh tidak adanya prestasi yang seharusnya menjadi hak kreditor, meliputi seluruh kerugian yang diderita sebagai akibat wanprestasi debitor. Sedangkan ganti rugi pelengkap (aanvullend vergaeding), merupakan ganti rugi sebagai akibat terlambat atau tidak dipenuhinya prestasi debitor sebagaimana mestinya atau karena adanya pemutusan perjanjian. ${ }^{15}$

Untuk membuktikan adanya kerugian yang menimbulkan hak baginya untuk memperoleh ganti rugi harus dikaji ada atau tidak hubungan kausal antara peristiwa yang merupakan penyebab (wanprestasi) dengan akibat yang ditimbulkannya (kerugian). Oleh karena itu, kunci keberhasilan gugatan ganti rugi terletak pada pembuktian adanya hubungan kausal antara wanprestasi dan kerugian.

Dengan demikian dalam tanggung gugat berdasarkan adanya wanprestasi, timbulnya kewajiban untuk membayar ganti kerugian tidak lain merupakan penerapan klausula dalam perjanjian, yang merupakan ketentuan hukum yang mengikat para pihak untuk ditaati. Sehingga bukan undangundang yang menentukan apakah harus dibayar ganti kerugian atau berapa besar ganti kerugian yang harus dibayar, melainkan kedua belah pihak yang menentukan syarat-syaratnya. serta besarnya ganti kerugian yang harus dibayar, dan hal ini

${ }^{14}$ Purwahid Patrik. (1994). Dasar-dasar Hukum Perikatan (Perikatan yang Lahir dari Perjanjian dan dari UndangUndang). Bandung: Mandar Maju. h. 11.

${ }^{15}$ ibid. 
berlaku sebagai undang-undang bagi mereka yang membuatnya.

Selain tanggung gugat atas dasar wanprestasi, dalam hukum perdata juga terdapat tanggung gugat atas dasar adanya perbuatan melanggar hukum (onrechtmatigedaad). Apabila tanggung gugat atas dasar wanprestasi berlandaskan pada adanya hubungan kontraktual yang dilanggar oleh salah satu pihak, maka tanggung gugat atas perbuatan melanggar hukum lahir dari perbuatan seseorang yang menimbulkan kerugian kepada orang lain. Tanggung gugat demikian didasarkan pada undang-undang yang lazimnya mengatur perbuatan seseorang dalam lapangan hukum keperdataan, yakni ada perbuatan yang sesuai hukum (rechtmatigedaad) dan perbuatan yang melanggar hukum (onrechtmatigedaad). Hal ini sejalan dengan asas umum dalam hukum perdata yang dikatakan bahwa siapapun yang tindakannya merugikan pihak lain, dan pihak yang menyebabkan kerugian wajib untuk memberi ganti rugi kepada yang menderita kerugian. Perbuatan yang merugikan tersebut dapat lahir karena: a. Tidak ditepatinya suatu perjanjian atau kesepakatan yang telah dibuat (yang pada umumnya dikenal dengan istilah wanprestasi); b. Semata-mata lahir karena suatu perbuatan tersebut (atau yang dikenal dengan perbuatan melawan hukum).

Kedua hal tersebut mempunyai konsekuensi hukum yang cukup signifikan perbedaannya. Pada tindakan yang pertama, sudah terdapat hubungan hukum antara para pihak, dimana salah satu pihak dalam hubungan hukum tersebut telah melakukan suatu perbuatan yang merugikan pihak lain, dengan cara tidak memenuhi kewajibannya sebagaimana yang harus dilakukan berdasarkan kesepakatan yang telah mereka capai. Tindakan yang merugikan ini memberikan hak kepada pihak yang dirugikan untuk meminta pembatalan atas perjanjian yang telah dibuat, beserta penggantian segala biaya, dan kerugian yang telah dideritanya.

Terkait dengan tanggung gugat atas dasar perbuatan melanggar hukum pada dasarnya harus dipenuhi unsur-unsur Pasal 1365 BW, yaitu: a. Harus ada perbuatan melanggar hukum; $b$. Ada kerugian; $c$. Ada hubungan sebab akibat; d. Ada kesalahan.

Wanprestasi yang dilakukan oleh pihak pengembang Apartemen Green Pramuka dengan tidak membangun prasarana, sarana dan fasilitas umum satuan rumah susun menimbulkan ia harus bertanggung gugat dengan melakukan pemenuhan prestasi sesuai yang pengembang janjikan kepada pembeli serta memberikan ganti rugi atas kerugian yang diterima pembeli dengan tidak memenuhi prestasi sesuai yang dijanjikan pengembang.

\section{Upaya Hukum Yang Ditempuh Pembeli Akibat Pengembang Wanprestasi Terhadap Prasarana, Sarana dan Fasilitas Umum Satuan Rumah Susun}

Sengketa dalam hubungan jual beli satuan rumah susun biasanya lahir dikarenakan adanya disinkronisasi di antara pengembang dan konsumen khususnya pada sengketa perdata, yaitu telah terjadi wanprestasi terhadap perjanjian. Sengketa perdata merupakan perkara atau sengketa yang terjadi di antara pengembang dan konsumen yang berkepentingan di dalamnya. Umumnya terjadi pelanggaran hak oleh pengembang sehingga merugikan pembeli yang dapat diselesaikan dengan cara damai di luar pengadilan dan diselesaikan di pengadilan.

Secara resmi sengketa konsumen dapat ditemui dalam Keputusan Menteri Perindustrian dan Perdagangan RI No. 350/MPP/Kep/12/2001. Pasal 1 angka 8 Kepmen No. 350/MPP/Kep/12/2001 menyatakan, bahwa sengketa konsumen antara pelaku usaha dengan konsumen yang menuntut ganti rugi atas kerusakan, pencemaran dan/atau yang menderita kerugian akibat mengkonsumsi barang dan/atau memanfaatkan jasa.

Dalam mengadakan perlindungan konsumen di Indonesia dilakukan berdasarkan asas, yaitu: 1. Asas manfaat; 2. Asas keadilan; 3. Asas keseimbangan; 4. Asas keamanan dan keselamatan konsumen; 5. Asas kepastian hukum.

Konsumen mempunyai berbagai macam hak yang menurut Pasal 4 UUPK melekat pada konsumen dan tidak boleh dilanggar oleh pelaku usaha. Meskipun begitu, dalam prakteknya sering terjadi pelanggaran terhadap hak-hak konsumen tersebut, yang kemudian berujung pada lahirnya sengketa antara produsen dengan konsumen dibagi menjadi 2 bagian yaitu penyelesaian sengketa di luar pengadilan dan penyelesaian sengketa melalui pengadilan.

Menurut penyelesaian sengketa di bidang Rumah Susun sendiri telah diatur dalam Pasal 105 dan 106 UURS. Ketentuan tersebut dapat dijadikan pedoman 
dalam setiap penyelesaian sengketa mengenai rumah susun. Penyelesaian sengeketa mengenai rumah susun terlebih dahulu diupayakan bermusyawarah mufakat, Namun jika musyawarah mufakat tidak tercapai, maka konsumen selaku pihak yang dirugikan dapat menggugat melalui pengadilan. Menurut Pasal 106 UURS siapa saja yang merasa dirugikan terkait dengan rumah susun dapat mengajukan gugatan ke pengadilan Penyelesaian sengketa juga dapat dilakukan di luar pengadilan berdasarkan pilihan yang disepakati pengembang dan konsumen yang bersengketa melalui arbitrase, konsiliasi, mediasi.

Pemilihan forum penyelesaian sengketa yang akan digunakan dalam menyelesaikan suatu sengketa konsumen adalah berdasarkan pilihan sukarela para pihak yang bersengketa, hal ini sesuai dengan yang diatur dalam Pasal 45 ayat (2) UUPK.

\section{Upaya Hukum Melalui Jalur Non-Litigasi (Di Luar Pengadilan)}

Menurut Pasal 47 UUPK, penyelesaian sengketa konsumen di luar pengadilan diselenggarakan untuk mencapai kesepakatan mengenai bentuk dan besarnya ganti rugi dan/atau mengenai tindakan tertentu untuk menjamin tidak akan terjadi kembali atau tidak akan terulang kembali kerugian yang diderita konsumen. Kemudian, bentuk jaminan yang dimaksud menurut penjelasan Pasal 47 UUPK berupa persyaratan tertulis yang menerangkan bahwa tidak akan terulang kembali perbuatan yang telah merugikan konsumen tersebut.

Diselenggarakannya penyelesaian sengketa konsumen di luar pengadilan dengan tujuan mencapai kesepakatan para pihak mengenai ganti kerugian, dan/atau mengenai tindakan tertentu untuk menjamin konsumen agar tidak mengalami kerugian lagi. ${ }^{16}$

Penyelesaian sengketa Di Luar Pengadilan dibagi menjadi 2 yaitu: 1. Penyelesaian sengketa secara damai, oleh para pihak sendiri yaitu konsumen dan pelaku usaha atau produsen; 2. Penyelesaian sengketa melalui Badan Penyelesaian Sengketa Konsumen (BPSK) dengan mempergunakan mekanisme konsiliasi, mediasi, atau arbitrase.

\footnotetext{
${ }^{16}$ Susanti Adi Nugroho. (2008). Proses Penyelesaian Sengketa Konsumen Ditinjau Dari Hukum Acara Serta Kendala Implementasinya. Jakarta: Kencana Prenada Media Group, h. 14.
}

\section{a. Penyelesaian Sengketa Melalui Jalan Damai (Secara Langsung)}

Menurut Pasal 19 ayat (1) dan (3) UUPK, bagi konsumen yang merasa dirugikan dapat menuntut secara langsung penggantian kerugian kepada pelaku usaha dan pelaku usaha harus memberikan tanggapan dan/atau penyelesaian dalam jangka waktu tujuh hari setelah transaksi.

Jika mengikuti ketentuan Undang-Undang No. 30 Tahun 1999 tentang Arbitrase dan Alternatif Penyelesaian Sengketa, berkaitan dengan penyelesaian sengketa konsumen, terdapat beberapa cara penyelesaian sengketa di luar pengadilan yakni melalui Konsultasi, Negoisasi, Mediasi, Konsiliasi, atau Penilaian Ahli. UUPK hanya mengatur 3 macam, yakni Arbitrase, Konsiliasi, dan Mediasi, yang merupakan bentuk atau cara penyelesaian sengketa yang dibebanan menjadi tugas BPSK.

Yang dimaksud dengan penyelesaian secara damai adalah penyelesaian yang dilakukan oleh kedua belah pihak yang bersengketa yaitu pelaku usaha dan konsumen tanpa melalui pengadilan atau BPSK, dan tidak bertentangan dengan UUPK. Penyelesaian sengketa konsumen secara damai dapat dikatakan sebagai penyelesaian secara kekeluargaan di mana para pihak yang bersengketa berkumpul dan bermusyawarah untuk menentukan besar ganti rugi. Kemauan dan kemampuan berunding sangat diperlukan disamping waktu, tenaga dan kesabaran dalam menemukan titik perdamaian.

Apabila penyelesaian sengketa konsumen secara damai tidak menemui kesepakatan, maka konsumen dapat menyelesaikan sengketa melalui BPSK atau mengajukan gugatan ke pengadilan yang berwenang.

\section{b. Penyelesaian Sengketa Dengan BPSK}

Mengikuti ketentuan Pasal 23 UUPK, penyelesaian sengketa konsumen melalui BPSK dapat ditempuh jika penyelesaian secara damai di luar proses pengadilan tidak berhasil, baik karena pelaku usaha menolak atau tidak memberi tanggapan maupun jika tidak terdapat kesepakatan.

BPSK merupakan lembaga khusus yang bertugas untuk menyelesaikan sengketa konsumen diluar pengadilan dengan tujuan sebagai salah satu sarana penyelesaian sengketa konsumen dan pelaku usaha dengan prinsip murah, cepat dan sederhana. Keanggotaan BPSK terdiri dari unsur pemerintah, 
unsur konsumen, dan unsur pelaku usaha yang mana merupakan amanat dari UUPK yang kemudian dipertegas oleh Kepres No. 90 Tahun 2001 tentang Pembentukan BPSK di 10 Kabupaten/Kota.

Putusan BPSK dapat diajukan keberatan oleh para pihak ke Pengadilan Negeri paling lambat 14 (empat belas) hari kerja sejak pemberitahuan putusan. Upaya keberatan tidak dengan semata-mata diajukan oleh para pihak, namun dengan melihat adanya tata cara penyelesaian sengketa konsumen oleh BPSK diatur dalam UUPK jo. Kepmendagri No. 350/MPP/12/2001 tanggal 10 Desember 2001 tentang Pelaksanaan Tugas dan Wewenang BPSK. Proses penyelesaiannya pun diatur sangat sederhana dan sejauh mungkin dihindari suasana yang formal. ${ }^{17}$

BPSK melakukan penyelesaian sengketa konsumen yang sistem penyelesaian sengketanya yang dapat melalui Mediasi, Konsiliasi, Arbitrase yang dapat dipilih dan ditentukan oleh para pihak yang bersengketa. Dalam menangani dan menyelesaikan sengketa konsumen tersebut, BPSK membentuk majelis, dengan jumlah anggota yang harus ganjil yang sedikitnya terdiri dari 3 (tiga) orang yang mewakili semua unsur, dan dibantu oleh seorang panitera. ${ }^{18}$

Tuntutan ganti rugi yang diajukan konsumen melalui BPSK sesuai dengan Pasal 23 UUPK yang menyebutkan "Pelaku usaha yang menolak dan atau tidak memberi tanggapan dan atau tidak memenuhi ganti rugi atas tuntutan konsumen sebagaimana dimaksud dalam Pasal 19 ayat (1), ayat (2), ayat (3), dan ayat (4) UUPK, dapat digugat melalui badan penyelesaian sengketa konsumen atau mengajukan ke badan peradilan di tempat kedudukan konsumen."

\section{Penyelesaian Sengketa Melalui Pengadilan}

Upaya-upaya yang telah dijelaskan diatas merupakan upaya penyelesaian sengketa di luar pengadilan. Gugatan yang diajukan oleh konsumen ini dilakukan setelah segala upaya yang ditempuh melalui jalur kekeluargaan, yaitu jalur Di Luar pengadilan tidak mencapai hasil seperti yang diharapkan bersama. Jika setelah semua itu tidak

17 Susanti Adi Nugroho. (2008). Proses Penyelesaian Sengketa Konsumen Ditinjau Dari Hukum Acara Serta Kendala Implementasinya. Jakarta: Kencana Prenada Media Group, h. 13.

18 Gunawan Widjaja dan Ahmad Yani. (2001). Hukum Tentang Perlindungan Konsumen. Jakarta: Gramedia Pustaka Utama, h. 78. berhasil, maka konsumen untuk mendapatkan haknya akan menempuh jalur hukum dengan jalan mengajukan gugatan ke pengadilan yang berwenang.

Menurut ketentuan Pasal 45 ayat (1) UUPK yang menyatakan bahwa setiap konsumen yang dirugikan dapat menggugat pelaku usaha melalui lembaga yang bertugas menyelesaikan sengketa antara konsumen dan pelaku usaha atau melalui peradilan yang berada di lingkungan peradilan umum. Jadi dapat disimpulkan bahwa penyelesaian sengketa konsumen dapat dilakukan melalui jalur pengadilan maupun jalur di luar pengadilan.

Berdasarkan Pasal 48 UUPK yang menyatakan bahwa penyelesaian sengketa konsumen melalui pengadilan mengacu pada ketentuan peradilan umum yang berlaku dengan memperhatikan ketentuan Pasal 45. Maka dengan merujuk pada Pasal 45 jo. Pasal 46 ayat (2), penyelesaian sengketa melalui pengadilan tetap dapat diupayakan walaupun telah dipilih upaya penyelesaian sengketa konsumen di luar pengadilan, dengan hanya berdasarkan alasan bahwa upaya penyelesaian tersebut tidak berhasil oleh salah satu pihak. Penyelesaian sengketa ditempuh melalui Pengadilan Negeri karena: a. Sengaja dipilih oleh para pihak. Dalam hal ini, konsumen yang merasa dirugikan dengan pelaku usaha sejak awal ingin sengketa diselesaikan melalui pengadilan. (Pasal 45 ayat (2) UUPK); b. Upaya penyelesaian sengketa di luar pengadilan melalui BPSK dinyatakan tidak berhasil oleh salah satu pihak yang bersengketa (Pasal 45 ayat (4) UUPK); c. Ada salah satu pihak yang merasa keberatan dengan keputusan Majelis BPSK, bahwa antara konsumen atau pelaku usaha merasa keberatan dengan keputusan Majelsi BPSK (Pasal 56 ayat (2) UUPK jo. Pasal 41 ayat (3) Kepmenperindag No. 350/MPP/Kep/ 12/2001.

UUPK memberikan jangka waktu 21 (dua puluh satu) hari untuk proses tingkat Pengadilan Negeri dan 30 (tiga puluh) hari untuk mengajukan keberatan ke Pengadilan Tinggi maupun kasasi ke Mahkamah Agung.

Secara umum, kelemahan penyelesaian sengketa melalui jalur pengadilan adalah penyelesaian sengketa melalui pengadilan sangat lambat, biaya perkara yang mahal, pengadilan pada umumnya tidak responsif, putusan pengadilan tidak menyelesaikan masalah, kemampuan para hakim yang bersifat generalis. 
Diantara sekian banyak kelemahan penyelesaian sengketa melalui jalur pengadilan tersebut, yang banyak dikeluhkan oleh para pihak adalah penyelesaian sengketa yang lama. Karena pada umumnya para pihak yang bersengketa dapat lebih memilih penyelesaian sengketa melalui jalur di luar pengadilan.

\section{PENUTUP}

\section{Kesimpulan}

Pihak pengembang selaku penjual satuan rumah susun dapat melakukan penjualan unit rumah susun yang dibangunnya sebelum pembangunan selesai melalui pembuatan akta PPJB dihadapan Notaris dengan memenuhi syarat dari Pasal 43 ayat (2) UURS khususnya dalam ketersediaan prasarana, sarana, dan utilitas umum yang menjadi perhatian utama dalam penulisan artikel ini, dan jika terjadi wanprestasi dalam pemenuhan prasarana, sarana, dan utilitas umum sesuai yang dijanjikan dalam PPJB tersebut pihak pengembang wajib bertanggung gugat kepada pembeli dengan melakukan pemenuhan prestasinya terlebih dahulu disertai dengan pemberian uang ganti rugi, dan bunga

Upaya hukum yang dapat ditempuh pihak pembeli akibat wanprestasi pihak pengembang terhadap prasarana, sarana, dan utilitas umum pada PPJB satuan rumah susun dapat diselesaikan melalui jalur non litigasi (di luar pengadilan) dan melalui jalur litigasi (melalui pengadilan), penyelesaian sengketa melalui jalur non litigasi (di luar pengadilan) dilakukan dengan cara damai (musyawarah mufakat) antara pihak pengembang dan pembeli dan juga bisa melalui BPSK.

\section{Rekomendasi}

Perlunya terdapat undang-undang tersendiri yang mengatur mengenai PPJB satuan rumah susun karena PPJB saat ini masih diatur dalam Keputusan Menteri Perumahan No. 11/KPTS/1994 yang dirasa belum terlalu mengikat para pihak.

Diperlukan lembaga pengawas khusus dalam menyelesaikan sengketa rumah susun ini khususnya dalam mengawasi pengembang rumah susun yang banyak melakukan kecurangan dalam pelaksanaan perjanjian jual beli satuan rumah susun sehingga sangat merugikan pembeli, dan untuk calon pembeli sendiri diharapkan akan ketelitian sebelum membeli dengan mencari informasi terlebih dahulu apakah rumah susun yang ditawarkan oleh pengembang tersebut aman untuk dimiliki sehingga dapar meminimalisir sengketa dalam jual beli satuan rumah susun kedepannya.

\section{DAFTAR PUSTAKA}

\section{Peraturan Perundang-undangan:}

Undang-Undang Dasar Negara Republik Indonesia Tahun 1945.

Burgerlijk Wetboek (BW).

Undang-Undang Nomor 8 Tahun 1999 tentang Perlindungan Konsumen.

Undang-Undang Nomor 1 Tahun 2011 tentang Perumahan Dan Kawasan Permukiman.

Undang-Undang Nomor 20 Tahun 2011 tentang Rumah Susun.

Keputusan Menteri Perumahan Nomor 11/ KPTS/1994 tentang Pedoman Perikatan Jual Beli Satuan Rumah Susun.

Keputusan Menteri Perindustrian dan Perdagangan Republik Indonesia Nomor 350/MPP/ Kep/12/2001 tentang Pelaksanaan Tugas dan Wewenang Badan Penyelesaian Sengketa Konsumen.

\section{Buku:}

Adrian Sutedi. (2010). Hukum Rumah Susun dan Apartemen. Jakarta: Sinar Grafika.

Agus Yudha Hernoko. (2009). Hukum Perjanjian Asas Proporsionalitas dalam Kontrak Komersial. Surabaya: Prenada Media Group.

Gunawan Widjaja dan Ahmad Yani. (2001). Hukum Tentang Perlindungan Konsumen. Jakarta: Gramedia Pustaka Utama.

Herlien Budiono. (2008). Kumpulan Tulisan Hukum Perdata di Bidang Kenotariatan. Bandung: Citra Aditya Bakti.

Maria S.W. Sumardjono. (2001). Kebijakan Pertanahan Antara Regulasi \& Implementasi. Jakarta: Kompas.

Munir Fuadi. (1999). Hukum Kontrak (Dari Sudut Pandang Hukum Bisnis). Bandung: Citra Aditya. Purwahid Patrik. (1994). Dasar-Dasar Hukum Perikatan (Perikatan Yang Lahir Dari Perjanjian dan Dari Undang-Undang). Bandung: Mandar Maju. 
Siswono Judohusodo. (1991). Rumah untuk Seluruh Rakyat. Jakarta: INKOPPOL, Unit Percetakan Bharakerta.

Subekti. (1995). Aneka Perjanjian. Bandung: Citra Aditya Bakti.
Susanti Adi Nugroho. (2008). Proses Penyelesaian Sengketa Konsumen Ditinjau Dari Hukum Acara Serta Kendala Implementasinya. Jakarta: Kencana Prenada Media Group.

Urip Santoso. (2014). Hukum Perumahan. Jakarta: Kencana Prenada Media Group. 